\title{
Mountains of Nostalgia
}

\section{Gropp C and Jaworowski S*}

Department of Consultation Psychiatry, Shaare Zedek Medical Centre, Jerusalem, Israel

*Corresponding author: Jaworowski S, Department of Consultation Psychiatry, Shaare Zedek Medical Centre, Jerusalem, Israel

\section{ARTICLE INFO}

Received: 幽 July 17, 2019

Published: 幽 July 23, 2019

\section{ABSTRACT}

Citation: Gropp C, Jaworowski S. Mountains of Nostalgia. Biomed J Sci \& Tech Res 19(5)2019. BJSTR. MS.ID.003378.
"By the waters of Babylon, there we sat down and wept, when we remembered Zion..." Psalm 137 (English Standard Version)

\section{Introduction}

It was an early evening in the fall when Ms. $\mathrm{N}^{*}$, a carer, was admitted to the Emergency Room (ER) of our General Hospital in Jerusalem. Ms. N, in her late twenties was from Sikkim in North India. The request for a psychiatric consultation described Ms. N as "being confused with unusual and strange behavior". Reportedly, Ms. N's work record was excellent and she was described as a particularly considerate, trustworthy and dedicated career, yet recently her behavior had changed: she had become moody, refused to eat, would talk to herself and burst out crying. Ms. N appeared distraught on the verge of tears: she could hardly sleep and was frightened because people she knew from her home were berating her behavior loudly especially at night. She had never experienced this before and denied using alcohol or drugs. In our hospital we do see the occasional tourist or foreign worker suffering from a psychotic disorder which colleagues have described as the Jerusalem Syndrome: few of the myriad pilgrims in Jerusalem are so deeply affected by spiritual tumult to cause a ruckus in the little streets of the old city promising doom or salvation [1].

Clearly Ms. N did not belong to this group. Her current condition was probably best described as a psychotic depression with mood congruent hallucinations a diagnosis that usually warrants a psychiatric admission especially where there is concern about suicidal risk. When I asked Ms. $\mathrm{N}$ if she had felt despair and perhaps even considered hurting or killing herself, her face contracted in various grimaces as if she was unable to decide whether to laugh or to cry. When I inquired about recent activities she asked me to clarify: she was working after all!
However, after some hesitation, she told me that she had been touring the country two weeks ago. The tour had included Mount Hermon, an elevation of modest height by world standards but still the highest mountain in the area flanked by even higher snowcovered peaks. I realized that a mountain might be the missing clue Ms. N's mysterious reaction.

Her affirmative verbal and body response to my question, if her visit there had anything to do with her current state seemed clear evidence: she all of a sudden smiled radiantly! It was as if Ms. N felt finally understood her predicament and all of a sudden all the pieces of the puzzle seemed to fit: Ms. $\mathrm{N}$ had apparently suffered from an acute bout of homesickness, asserting with a sigh: 'yes, it is very, very hard to be so far away from home for such a long time!' Ms. N's condition was similar to the clinical entity described by Johannes Hofer in Swiss mercenaries far from home in his classic 17th century medical dissertation on homesickness, he named Nostalgia. The Greek nostos, homeland, was taken from Homer's Odyssee [2]. These Swiss soldiers would be painfully reminded of the lush alpine meadows of home whenever they heard the sound of familiar melodies [3,4] suffering from physical sickness with considerable mental anguish, sometimes even dying from grief. The consensus cure was return to the mountains [3,4]. If Ms. N indeed recovered completely or if she heeded my advice to sojourn in the mountains at home, I do not know, as she never answered our follow up calls.

\section{Discussion}

Like Ms. N, migrant workers throughout the world travel far, for gainful employment in order to sustain their families and to ensure 
a better future for their children with their earnings [5]. Israel itself a society of immigrants [6], is rated eleventh on a world longevity ranking [7] with a considerable number of foreign care workers for the elderly [8].

Nostalgia has been recently studied in Syrian refugees living in Saudia Arabia [9]. The decreased optimism of the refugees was found to be moderated by their dispositional resilience.

Ms $\mathrm{N}$, until recently also manifested a sense of dispositional resilience including a sense of control, commitment and challenge toward her new environment. These personality traits have been associated with the hardiness construct [10]. In her book "The Future of Nostalgia [11]", Svetlana Boym described two forms of Nostalgia: a and a reflective nostalgia. In the restorative nostalgia there is a desire to recreate and relive the past experience. In the reflective nostalgia, the person accepts the past nature of the experience but is nevertheless able to positively savor the emotions evoked by the recollected experience.

Perhaps Ms. N was able to transition her condition into a more reflective form of nostalgia through the insight provided by the psychiatric consultation. Once recognized, her difficulty was after all easy to empathize with since both authors of this article are themselves emigrants and therefore prone to occasional bouts of

ISSN: 2574-1241

DOI: $10.26717 /$ BJSTR.2019.19.003378

Jaworowski S. Biomed J Sci \& Tech Res

This work is licensed under Creative Commons Attribution 4.0 License

Submission Link: https://biomedres.us/submit-manuscript.php
Nostalgia.

*: Identifying details were modified significantly for privacy.

\section{References}

1. Bar El Y, Durst R, Katz G et al. (2000) Jerusalem Syndrome. British Journal of Psychiatry 176: 86-90.

2. Homer (2006) The Odyssey, translated by Rober Fagles. Penguin Books, London, UK.

3. (1976) Editorial, Nostalgia: a vanished disease. British Medical Journal 1(6014): 857-858.

4. Fuentenebro de Diego F, Valiente Ots C (2014) Nostalgia: a conceptual history. History of Psychiatry 25(4): 404-411.

5. Thompson Fullilove M (1996) Psychiatric Implications of Displacement: Contributions from the Psychology of Place. American Journal of Psychiatry 153(12): 1516-1523.

6. Schafferman KT (2008) Israel: A society of immigrants. Parliament (In Hebrew).

7. (2019) World population review.

8. Mazuz K (2015) Elderly care between global and local services: the use of somatic care practices. BMJ case reports.

9. Wildschut T, Sedikides C, Alvividy D (2019) Hanin: Nostalgia among Syrian refugees. European Journal of Social Psychology.

10. Bartone PT (2007) Test retest reliability of the dispositional resilience scale-15, a brief hardiness scale. Psychol Rep. 101(3): 943-944.

11. Boym S. (2001) The Future of Nostalgia. Basic Books.

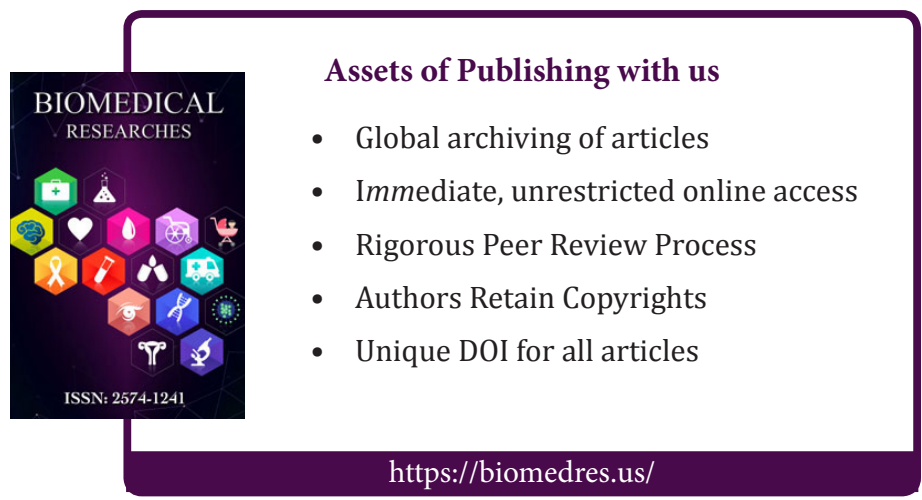

